\title{
Assessing the Effects of Credit Risk Management on Financial Performance of Selected Banks in the Ghana Stock Exchange
}

\author{
Joshua Niibton Laar Luther Ntim Adjei* \\ School of Business, Valley View University P.O.Box 183, TMA. Techiman, BE/R, Ghana
}

\begin{abstract}
The study explored the effect of credit risk management and its relationship to financial performance in the Ghanaian banking sector. This study adopted the explanatory research design. In this study, census sampling was used to select four (4) banks. These banks were Access Bank, Agricultural Development Bank, Ghana Commercial Bank, and Republic Bank. Data for the study constituted secondary data which were obtained from published audited annual report of the banks and the Ghana Banking Survey. The study adopted the regression analysis. The results indicated that credit risk has a negative relationship with performance in the banking sector. Specifically, credit risk related negatively with capital adequacy ratio, asset quality, management quality, earnings and profitability and liquidity. The concept is that increase in credit risk means bad credit risk management and vice versa. The implication therefore is that an increase in credit risk management give rise to increase in financial performance. The study recommended that training programmes be organized for credit officers on effective client monitoring. For the customers, there is the need to design and implement adequate credit management programmes to educate clients on proper management of loans. The policy and procedures should be living documents that reflect current and emerging credit practices.
\end{abstract}

Keywords: Credit Risk Management, Financial Performance, Ghanaian Banking Sector.

DOI: $10.7176 /$ RJFA/11-12-08

Publication date:June 30th 2020

\section{Introduction}

Universal access to financial services is a critical component which drives development since it includes the vulnerable such as low-income household in the society to participate in the governance of the country (Iqbal \& Sami, 2017). When people get access to financial services, it transforms their production through investment, which eliminates them from poverty. Studies have propounded the fact that the fundamental activity of the banking sector is to make credit available to its customers (Bothra, 2018a; Misra \& Aspal, 2013). In this way, customers can increase their economic activities (Sen, 2000, cited in Iqbal \& Sami, 2017). However, within the short and medium terms, making finance available has its adverse impact on the rural populace; hence, it is important that various measures be put in place to overcome these barriers so that the long-term convergence of productivity among the different sectors of the economy could be realized. When this is done, the expectation is a broad spectrum of opportunities that might arise from this progressive change and a renewed mindset of the banks to take up challenges affecting loan performance.

While financial institutions have encountered several difficulties over the years for a multitude of reasons, the primary cause of these challenges continues to be directly related to lack of credit standards for borrowers, poor portfolio risk management, lack of attention to changes in economic circumstances leading to deterioration in the credit standing of the institution (Kalu, Shieler, \& Amu, 2018). According to Olabamiji and Michael (2018), credit is the most important and the most evident source of loan risks; however, in all banks ' operations, including the bank and trading books, on and off the balance sheet, there are other sources of credit danger. In multiple financial instruments other than loans, banks are increasingly confronted by loan danger, such as loans, interbank transactions, commercial funding, foreign exchange transactions, swaps, bonds, equities, choices, obligations, and guarantees being broadened as well as transactions settled.

According to Jones (2018) credit management policies includes the establishment of formal, legitimate and legal procedures that maintains that the proper authorities are responsible for the award of credit and to maintain that the credit awarded goes to the right person and that the granted amount is used for the intended purposes with the aim of investing in productive ventures or for business which are economically or technically viable. Also, the policies include ensuring that the right amount of credit is granted, the credit granted is recoverable and ensuring that there is an adequate flow of information within and across the organization to credibly monitor the credit awarded (Ofosu-Hene \& Amoh, 2016).

The primary purpose of credit risk management is to maximize the risk-adjusted return rate of a bank by keeping an exposure of credit risk within acceptable parameters that leads to improvements in economic performance (Olabamiji \& Michael, 2018). Banks, therefore, need to manage the credit risk inherent in the entire portfolio as well as the uncertainty in individual credits or transactions. Financial institutions should also consider the relationships between credit risk and other risks as well as their impact on financial performance. Effective credit risk management is a key aspect of an integrated risk management strategy, which is crucial to a banking 
organization's long-term achievement as well as its economic results (Taiwo, Ucheaga, \& Achugamonu, 2017). Therefore, a strong capital base is needed through effective credit management is to meet the challenges posed by the financial and operational crisis, technological innovation, and to strengthen the system. This is because the efficiency and effectiveness of the operation of a bank depend primarily on what constitutes effective credit management (Gaughan, 2010). Credit risk management, therefore, influences the financial performance of a bank.

Financial performance refers to the measure of how well a bank can use assets from its primary mode of business and generate revenues (Karugu \& Ntoiti, 2015). It is necessary to assess the economic health of a bank over some time to compare or compare comparable companies in the same sector or sector in aggregation. In risk management, the financial performance of a firm is assessed by evaluating its profitability, liquidity, and capital adequacy (Kodithuwakku, 2015). For this study, the financial performance is measured using the CAMEL model which has been the tool used by most researchers (for example; Bothra, 2018; Khoury \& Salem, 2018; Rostami, 2015) in evaluating banks' financial performance. The tool measures financial performance based on five parameters; capital adequacy, asset quality, management efficiency, earnings efficiency, and liquidity.

With the current downturn of turbulence in the Ghanaian-banking sector coupled with higher inflation, highinterest rates, fluctuating fuel prices, and the depreciation of the Ghanaian cedi, it is only desirable that banks adopt efficient credit management. Management failure to adopt prudent measures on credit management has resulted in banks' insolvency in the country, and one can argue that the issue of credit management has been dowCRMayed by most banks. It is, therefore, urgent to further delve into the situation to raise awareness through empirical evidence on credit risk management and its implications on banks' financial performance.

\subsection{Statement of the Problem}

In Ghana, the Bank of Ghana (BoG) Banking sector report (BoG, 2017a) indicated that banks' stock of nonperforming loans increased from GHф6.14 billion as at the end of December 2016 (39.0\% year-on-year growth) to GHф8.58 billion in December 2017 (39.8\% year-on-year growth). This is coupled with a loss of confidence of Ghanaians in the financial sector since most of the indigenous banks in Ghana have been faced with severe insolvency and liquidity challenges over the years, with constant clearing deficits (BoG, 2017b). A case in question is that of UT Bank, Capital Bank, UniBank, Sovereign Bank, and Royal Bank. All these banks faced a significant capital shortfall with some registering negative Capital Adequacy Ratio (CAR), capital deficits, rise in nonperforming loans rendering the banks insolvent and unable to meet daily liquidity obligations of their customers. The apparent reason for this was the lack of adequate credit risk management to control the situation (Ofosu-Hene \& Amoh, 2016).

According to Blanch (2011), sustainable growth in the banking sector is impossible without a proper formulation and implementation of innovative measures in managing credit risk. Added to this is a study by Hurka (2017) that, within the financial sector, the issue of credit management is very relevant, and no bank can thrive without effective credit risk management. In line with this concern, this study raises the following questions:

i. Is there a meaningful relationship between credit risk management and capital adequacy of banks in Ghana?

ii. Is there a significant correlation between credit risk management and the asset quality of banks?

iii. Is there a meaningful relationship between credit risk management and management quality of banks in Ghana?

iv. Is there a significant correlation between credit risk management and an earnings efficiency of banks in Ghana?

v. Is there a meaningful relationship between credit risk management and the liquidity of banks in Ghana?

\subsection{Objective of the Study}

\subsubsection{General Objective}

The study seeks to explore the effect of credit risk management and its relationship to financial performance in the Ghanaian banking sector.

\subsubsection{Specific Objectives}

The specific objectives seek to:

i. determine if there is a meaningful relationship between credit risk management and capital adequacy of banks in Ghana,

ii. examine if there is a significant relationship between credit risk management and the asset quality of banks,

iii. explore if there is a significant relationship between credit risk management and management quality of banks in Ghana,

iv. determine if there is a significant relationship between credit risk management and an earnings efficiency of banks in Ghana,

v. Examine if there is a meaningful relationship between credit risk management and the liquidity of banks 
in Ghana.

\subsection{Significance of the Study}

The research seeks out to thoroughly assess the implications of credit risk management on the financial performance of banks in the Ghanaian perspective. The study will help various stakeholders in banks, mainly management and shareholders, to identify gaps inherent in their credit risk management and find ways of improving their credit portfolio.

The results of the study will go a long way to assist the management of the selected banks in understanding and appreciating the underlying factors behind the quality of their credit risk management. It will help management to develop a credit risk management strategic plan that will enable them to conduct timely and useful analysis to mitigate deterioration of the quality of their credit portfolio.

To the customer, efficient credit risk management of the banks will ensure the continual availability of credit facilities to enhance their businesses.

Besides, the outcome of this research would help future researchers who would try to do additional research on this field of study. The result of this study would also be a reference material in the library.

\subsection{Scope and Limitation(s) of the Study}

Contextually, this study focused on credit risk management and its implication on the financial performance of banks. The study was limited to selected banks on the Ghana stock exchange and operates within the Bono East Region, Techiman. Specifically, the study targets GCB Bank Limited, Agricultural Development Bank (ADB), Access Bank, and Republic Bank.

The study is limited in the number of banks used. Even though several banks exist in the Ghana Stock Exchange, this study was limited to the selected banks which operate in the Bono East Region. Also, secondary data was used, and this prevented the interaction of the researcher with respondents to clarify some issues. This also limits the study

\section{Literature Review \\ 2.1 Conceptual Review}

\subsubsection{Definition and Concepts of Credit Risk and Credit Risk Management}

The credit risk is the present and prospective risk of income or assets resulting from the inability of a borrower to fulfil the conditions of any agreement with the bank or otherwise to carry out as agreeable (Muritala \& Taiwo, 2016). In all operations, the credit risk relies on counterparty, issuer, and borrower performance. Credit risk is identified. It occurs when bank funds, whether reflected on or without the balance sheet, are expanded, engaged, invested, or otherwise exposed using real or implied contractual arrangements. Activities such as inability to pay due obligations and moratorium or changes in credit rating and restructure are normally included (Mohamed, 2016). Credit incidents include occurrences such as bankruptcy. Alshatti (2015) noted that the credit risk refers to the risk in case of a default or the danger of a delay in repairing the loan, that an asset or loan will be irrecoverable.

As stated by Boye and Kwabena (2014), loans are the largest and most obvious source of credit risk for most banks. However, on and off the balance sheet, there are additional credit risk pockets, such as the investment portfolio, overdrafts, and loan letters. A bank is also a danger for loans for many goods, operations and services such as derivatives, foreign exchange, and financial management. By Agyiri (2012), a credit risk management procedures of a bank will either reduce or increase the risk of reimbursement. The original lending method, sound underwriting norms, a balanced and effective approval process, and skilled lending employees, is the primary protection of a bank against excessive credit risk. These factors exert a powerful influence on credit quality because a bank can not readily overcome borrowers with questionable ability or personality. Borrowers who have a bad or marginal financial performance or who depend on unsuccessful predictions for their repayment will soon become disruptive due to private or external economic pressure (Gong, 2014). The credit risk management, however, after a loan is given, can be undermined by insufficient credit structure or tracking if the original credit choices are sound. Traditionally, banks have concentrated on handling their general credit risk by overseeing individual loans (Yeboah-Mensah, 2015). While this focus is crucial, in terms of portfolio sections and the entire portfolio, banks should also regard credit risk management.

Therefore, effective credit risk management needs the board and management to comprehend and regulate the risk profile and loan culture of the bank. To accomplish this, they need a thorough knowledge of the portfolio's structure and its inherent risks. They must comprehend the product mix, levels of sector and geography, average risk ratings, and other aggregate features of the portfolio (Maino \& Tintchev, 2012). They must be certain that the strategies, procedures, and procedures introduced to regulate the hazards of individual loans and portfolio sections are sound, and that loan staff adhere to them. The successful management of credit risk is dependent on the ability to measure it. The main challenge of this is how to precisely measure credit risk exposure and portfolio level because as the level of credit risk rises, the realized rate of return on the loan portfolio is reduced and the required 
level of capital increases (Cole et al., 2012). Muhammad and Garba (2014) identify two important tools that can be used in assessing or measuring credit risk. These include Default ratio (DR) and Cost per loan advanced.

Default Ratio (DR): DR is a ratio that determines the amount of non-performing loans as against the total loans and advances over a period. It shows the percentage of loans and advances that were not paid over a period. It also shows the efficiency of management has performed in controlling their loan portfolio over a period. DR ratio can be calculated as:

DR Ratio $=\frac{\text { Non-performing Loans }}{\text { Total Loans and Advances }}$

Cost Per Loan Advanced Ratio (CLA): CLA is the average cost per loan advanced to a customer in monetary terms. The purpose of this is to highlight the effectiveness of the distribution of loans to clients (Kolapo et al., 2012). CLA ratio can be calculated as:

CLA Ratio $=\frac{\text { Total Operation Cost }}{\text { Total Amount of Loans }}$

\subsubsection{Relationship between Credit Risk Management and Capital Adequacy of Banks}

Capital is the pillar of the economic strength of a bank. It promotes bank operations by offering a buffer to absorb unforeseen losses from its operations and, in case of issues, allowing the bank to continue to function in a sound and feasible way while addressing or resolving the issues (Kalu et al., 2018). Maintaining a bank's appropriate capital reserves can create trust in the bank's economic soundness and stability by continuing to ensure that it fulfils its commitments to depositors and creditors (Nawaz, 2012). A measure of a bank's capital strength is the equity ratio, which is the quantity of regulatory capital expressed by a bank as a proportion of its risk-weighted assets. The' Capital Adequacy ' prudential guidelines set out the three primary aspects that determine the capital adequacy of a bank (Oluwafemi, Israel, \& Simeon, 2014). These are exposure-related credit risk; market risk from banking operations and the type and quality of capital retained to promote these exposures.

Epure and Lafuente (2015) studied the impact of risk on the performance of banks in the Costa-Rican banking industry during 1998-2007. The results showed that performance has an inverse relationship with credit risks and capital adequacy related positively with performance. Muritala and Taiwo (2016) claim that loans are the biggest and most evident cause of credit risk, while others are discovered in the multiple operations with which the bank itself has been engaged. It is, therefore, a necessity for each bank in the world to be conscious of the need to define measure, monitor, and regulate credit risk while also determining how credit hazards can be reduced. This implies that a bank should have sufficient assets against these hazards and that the risks incurred are properly compensated for them. This is specified in Basel II, which regulates the amount of capital required by banks to guide them against these kinds of economic and operational hazards (Kurawa \& Garba, 2014).

According to the Basel Committee on the Banking Supervision, banks should be able to set general loan boundaries at the level of individual borrowers and counterparties and organizations of related counterparties aggregating distinct kinds of exposures in an incomparable and meaningful way, both in the banking and trading books and on and off the balance sheets (Badu, 2012) — Maintaining a suitable credit management, measurement and tracking process, creating adequate credit risk controls and the role of credit risk measurement, tracking and control supervisors as part of the general risk management strategy. The more assets a bank has, the more it protects its creditors or the government insurance organization, and the higher the loss of capital that can be maintained without bankruptcy (Coast, 2017). There is a loss of capital (given uncertainty) and an increase in risks if the bank does not handle the risk through the distribution in loans, and if the borrower fail to make his or her obligations, the bank's equity serves as an hedge against uncertainty.

Capital Adequacy degree is a measure of the amount of bank equity as a percentage of risk-weighted loan exposure (Abayomi \& Daniel, 2011). Capital adequacy increases the strength of the bank, which improves the solvency of the bank and the capacity to absorb the loan loss and protect the bank from bankruptcy. Alshatti (2015) has asserted that the capital adequacy ratio doesn't affect the profitability of Jordanian Commercial Banks. However, Poudel 92012) found a significant negative association between capital adequacy ratio and bank performance in the Nepalese context. Likely, Olabamiji and Michael (2018) also found that the capital adequacy ratio has an inverse impact on banks' performance. Bhattarai (2018) has found that the capital adequacy ratio was significant and hurt bank profitability. In this scenario, a negative relationship is expected between the capital adequacy ratio and bank profitability.

\subsubsection{Relationship between Credit Risk Management and Asset Quality of Banks}

The importance of CRM has been further elaborated in many recent studies. Some studies even associate poor asset quality of banks to bad CRM of banks. For instance, Chaplinska (2012) analyzes Latvian commercial banks in the wake of a crisis. During this period, she observes that the volume and quality of assets of the bank decrease rapidly. This, in her estimation, is a result of inefficient management of credit risk in Latvian banks. According to Muritala and Taiwo (2016) increased the number of branches and customers and the quest to get more customers to push some banks to relax their credit management policies resulting into many issues such as bad loan assessment scheme, financial crimes, bad asset quality accumulation among others. Like the banking company, the need for risk management is intrinsic in the banking sector. Poor asset quality and low liquidity concentrations 
are the two main causes of bank failures and are the main sources of credit risk management risk. (Alshatti, 2015). Increases in credit risk raise the marginal cost of debt and equity, which in turn increases the cost of funds for the bank and hence worsening the quality of assets of the bank.

There are multiple equations used by researchers for calculating credit risk. The LOSRES ratio is a calculation of the valuation of a bank's assets, indicating how much of the overall portfolio was given but did not charge off. The higher the ratio, the lower the price; thus, the greater the risk of the portfolio (Mumbi \& Omagwa, 2017) would be. Assessing the impact of loan activities on bank risk, Ofosu-Hene and Amoh (2016) used the ratio of bank loans to assets (LTA). The reason to do so is that bank loans are relatively illiquid and subject to higher default risk than other bank assets, implying a positive relationship between LTA and the risk measures. In contrast, relative improvements in credit risk management strategies might suggest that LTA is negatively related to bank risk measures (Abayomi \& Daniel, 2011).

\subsubsection{Relationship between Credit Risk Management and Management Quality of Banks}

Management of financial institutions is responsible for the approval and formation of credit risk (Chaplinska, 2012). Also, they are responsible for reviewing strategies of the bank including delineating bank's overall risk tolerance about credit risk, ensuring that bank's overall credit risk exposure is maintained at prudent levels and consistent with the available capital (Kurawa \& Garba, 2014). They also guarantee that top management, as well as credit risk management people, have sound skills and knowledge to fulfil the risk management role, ensuring that the bank implements sound basic values that enable credit risk identification, measurement, tracking, and control (Muritala \& Taiwo, 2016). They are also accountable for ensuring that adequate credit risk management plans and processes are in place.

According to the Basel Committee (1999), the correct loan approval method should include appropriate guidelines on both form and methodology for assessing the creditworthiness of borrowers, establishing credit line and interest rate suitable for the danger and credit of borrowers. Lenient credit underwriting can result in losses for financial institutions, particularly when debt repayment can not be requested or collateral can not be taken in time (Badu, 2012). A deficiency in underwriting norms and credit monitoring results in many loan hazards. Credit officers can lead to bad lending practices, ineffective administration and ultimately a loss to financial institutions without the required knowledge in the operations they are accountable for, be it credits, investment, management of issue resources or fresh goods (Coast, 2017). The risk will improve unless management receives precise and timely credit reports regularly. The reports shall contain significant data concerning the process of underwriting such as economic trends, change in the structure of the industry, or market share, commodity prices, exchange rates, including past due credits, credit concentrations, as well as analysis of problem loans.

Moreover, rapid growth and entry into new markets can tempt the management to lend without sufficient financial and economic analysis (Poudel, 2012). Management can support loan choices by using easy credit quality indicators such as the features of borrowers, the present and expected value of collateral or help from a parent business or associated businesses to promote faster decision-making. Another significant issue is financial institutions that do not carefully evaluate risks when introducing fresh products and do not install a risk management system before launching new products (Opoku, 2015). With fast loan development and increased competition, financial institutions are being forced to market without adequate testing to introduce fresh products and services. This practice may lead to severe issues for several banks, not in line with the principle of adequate loan underwriting (Coast, 2017).

Part of credit risks arises when boards or management of financial institutions can not supervise different units to guarantee that they comply with the policy properly (Bhardwaj, 2013). Financial institutions are aimed at maximizing revenue and providing shareholders with the most value by providing a range of financial services and in particular, by managing hazards. Most financial institutions have crashed or encountered financial problems owing, among other things, to inefficient credit risk management schemes characterized by elevated rates of insider loans, speculative loans and elevated credit concentration in some industries (Agyei, 2017). Credit risk management procedures and bad credit quality remain a dominant cause of bank failures and global banking crises. The extent to which banks handle their credit risk affects their economic performance or survival as a whole.

As a consequence of the poor credit risk management scheme, the causes of high non-performing loans can influence profitability (Asante, 2015). Consequently, the inability to handle credit risk efficiently leads mostly to the financial crisis of the banks. Effective procedures in credit risk management decrease client default risk.

\subsubsection{Relationship between Credit Risk Management and Earnings Efficiency of Banks}

Earnings are an indicator of banks' capacity to carry risk and increase their capital. Li and Zou (2014) employed the unbalanced panel regression in studying the impact bank regulations, financial and institutional development have on profitability in the Middle East and North Africa from 1989 to 2005 show that there is a positive relationship between credit risk bank capitalization and banks profitability. Afriyie and Akotey (2013) carried out a project which looked at the impact of CRM on profitability. This study displayed that there is a substantial correlation between bank performance (in the field of profitability) and credit risk management. Kayode, Obamuyi, Owoputi, and Adeyefa (2015) estimated the effect of credit risk on the profitability of Nigerian banks. Data on 
credit risk and profitability ratios were collected from 2004 to2008. The analysis of this data involved descriptive, correlation, and regression techniques. The result was that CRM has a substantial influence on the profitability of Nigerian banks. Other findings of the study showed that a rise in credit risks negatively affects profitability and liquidity. Wenner, Navajas, Trivelli, and Tarazona (2007) spells out that CRM enables financial institutions to become viable and attain sustainable growth, leads to solvency and reduces costs and improve profit margins. Odonkor (2018) also identifies you reduce earnings volatility, avoidance of losses. It acts as a decision aid to bankers, better risk-return, avoidance of pitfalls like credit concentrations, lack of credit discipline, aggressive underwriting to high-risk counterparts, and products at inadequate prices.

\subsubsection{Relationship between Credit Risk Management and Liquidity Position of Banks}

Nguyen (2016) defined liquidity risk as to the likelihood that a bank may not be able to fulfil its commitments to its depositors and provide the requirements of borrowers by instantly converting assets into liquid assets with minimum losses with the capacity to borrow funds when needed, while at the same moment having sufficient resources at its disposal to conduct lucrative securities trading. Liquidity is a need for economic organizations to offset anticipated and unexpected balance sheet changes to boost development (Van Greuning \& Brajovic Bratanovic, 2009). Some banks, however, incorporate the need to plan for development and unexpected credit expansion; the risk here should be more properly considered as the potential for financing crisis (Nguyen, 2016). A more liquid bank will be in a better position to fulfil its customers ' economic requirements and thus generate more value. The development of bank liquidity is strongly linked to bank value (Rundassa \& Batra, 2016). Banks as Financial Institutions have liquidity development as their primary service, but the conduct of individual financial institutions can destroy this good (Ahmadyan, 2018). A liquidity loss shows that if customers turn up, they can not satisfy the demand, and thus, the crisis can grow (Wenner, Navajas, Trivelli, \& Tarazona, 2007b).

The monetary capability of a bank is essential for its success. Managers have the responsibility to combat credit risk and boost stockholders' value. This is extremely important because, given the role performed by banks of being a financial mediator between surplus units and deficit units, illiquidity can lead to adverse effects by not its short term financial obligation. This adverse is popularly known as financial distress. Financial distress is the inability in terms of meeting financial obligations to account for payables on time (Serwadda, 2018).

Abderahim (2013) realized that liquidity and bank size affected the effectiveness of credit risk Management significantly. According to Ofosu-Hene and Amoh (2016), there are two fundamental circumstances from which liquidity risk may arise. First, the depositors of the banks may seek to cancel their economic allegations immediately. In this respect, by resorting to borrowing or selling off assets, the bank may need to satisfy this sudden demand. Second, banks are providers of off-balance-sheet credit commitments as well as liquidity risk. If borrowers decide to take advantage of their credit commitments, they must have instant funds to finance it rapidly, hence the liquidity demand. According to the Basel Supervisory Committee (2008), The banks ' fundamental function in transforming short-term deposits into long-term loans during maturity makes them fundamentally susceptible to the bank's liquidity risk as an organization and the (systemic) market as a whole.

A bank's liquidity is usually evaluated as the proportion between liquid money assets and total assets. Following the traditional notion of liquid assets in the literature on bank leadership, the definition of liquid assets involves cash and bank balance, cash on call, brief notice and short-term investment (Gladys, 2012). A higher liquidity ratio is generally understood to have a beneficial impact on a bank's stability. Excessive investment in liquid assets, however, is likely to impact the bank's profitability; a trade between liquidity and profitability is therefore essential

Conceptual Framework for the Study

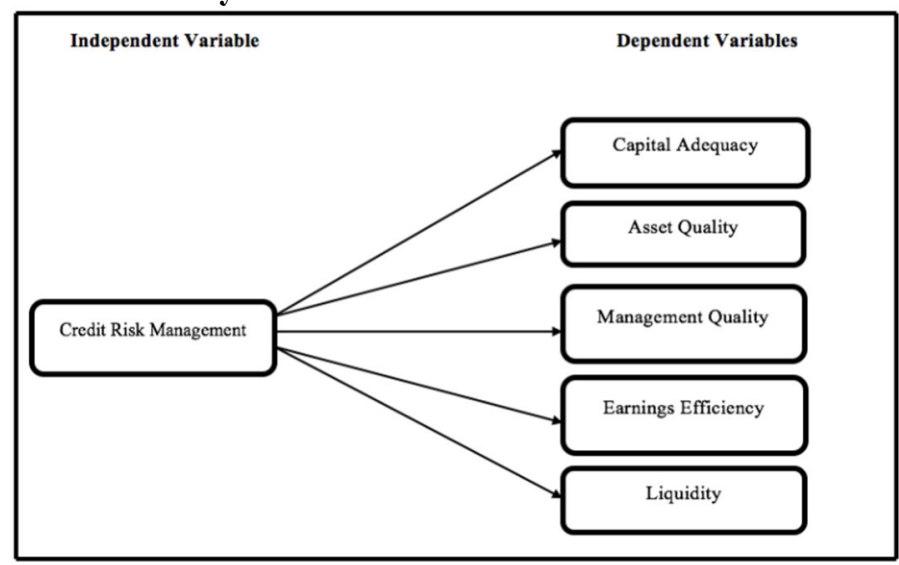

Figure 1: Conceptual Framework for the Study

The researchers considered the determination of credit risk management, as indicated in earlier studies (Agyei, 2017; Olabamiji \& Michael, 2018; Taiwo et al., 2017). In their studies, credit risk management was taken as the 
ability to minimize the ratio of non-performing loans of a bank to its total loans and advances. This is in accordance with the definitions of sound credit risk management as systems (which include risk identification, measurement, assessment, monitoring, and control) of policies and strategies (guidelines) which clearly targets the minimization of non-performing loans and through effective credit portfolio management; that is, how loans were originated, appraised, supervised and collected (Chen \& Pan, 2012; Nawaz, 2012; Kodithuwakku \& Lanka, 2015). For the components of the CAMEL as a measure of the financial performance of the banks, the study adopted the ratio of Equity to total asset as a measure for bank capital adequacy; the ratio of provision for bad debt to advances as the measure for asset quality; a ratio of operational costs to the total generated revenues as management efficiency; the return on average assets as earnings efficiency and a measure of net loans to total assets as liquidity.

\subsection{Theoretical Reviews}

Theories used for this study included the asymmetry theory, the credit theory of money, and the principal-agency theory. These theories underline concepts of credit risk management. On the financial performance of the banks, the study adopted the CAMEL model as the theoretical model.

\subsubsection{Asymmetry Theory}

This research anchor on the theory of information asymmetry as the theory is very important to this research. The theory of information asymmetry elucidates the fundamental data that lenders and company owners need to know about future hazards and returns connected with investment projects for which the funds are allocated. Ennew and Binks (1995) cited in Afriyie and Akotey (2013) observed that perceived asymmetry of data presents two issues for banks: moral hazard (monitoring entrepreneurial conduct) and negative selection (making mistakes in lending choices). This means that the "5cs" (character, ability, assets, collateral, and circumstances) must be properly assessed before credit can be given. This is because the information is not freely accessible to banks to screen loan requests and track borrowers. When evaluating loan applications, bankers face an information asymmetry scenario. Binks and Ennew (1997) quoted in Kessey (2015) asserted that information asymmetry occurs when a loan-taking borrower generally has better data about the prospective hazards and returns connected with investment projects for which the funds are allocated. On the other side, the banker does not have enough data about the entrepreneurs. In the same vein, Olabamiji and Michael (2018) also observed that the extent to which bank executives understand more about the company than shareholders as a group is information asymmetry.

According to Opoku (2015), one factor that exists between financial institutions and borrowers is information asymmetry. This phenomenon makes it difficult for banks to identify credible borrowers from bad ones. Therefore banks must put systems in place to analyze and evaluate the creditworthiness of borrowers to avoid adverse selection and moral hazard (products of information asymmetry) which cause enormous accumulation of credit risks in their records.

\subsubsection{Credit Theory}

The credit theory of money suggests that when an entrepreneur borrows from a bank, two obligations come forth. First, the entrepreneur must pay the debt owed to the bank according to the stipulated and signed contract terms and second, the bank must hold the entrepreneur in debts and to clear the entrepreneur of all debts after the debt has been paid (Diamond \& Rajan, 2006). The theory also suggests that lending to an SME is a contractual agreement between the bank and the SME. It is an agreement requiring the fulfilment of obligations on both parties and defaults in those obligations by either party may have negative consequences on the relationship between the parties, such as refusal to grant future loans to a defaulter (Graeber, 2011).

The contractual link between the lender and the borrower can be defined in terms of the principal-agent theory (Eisenhardt, 1989 cited in Murigi \& Thuo, 2018). Traditionally, the theory states that a contractual relationship exists between a principal (the bank) and the agent (the borrower). Berger and Udell (1990) as cited in Adarkwa (2011) emphasize that the derivation of the ideal type of the loan agreement is one of the most basic applications of agency theory to the connection between lender and borrower. This issue is traditionally regarded in the context of expensive state verification introduced by Townsend (1979) in a path-breaking article cited in Boateng (2017). The main agent theory's essence is that the agent, who does not have any wealth of his own, borrows cash from the principal to operate a one-shot investment project. Only the agent voluntarily observes the project result. Thus, the officer faces a moral dilemma to either announce or disguise the project's real result. According to Townsend (1979) ascited in Boateng (2017), this situation describes the ex-post moral hazard, as opposed to the situation of ex-ante moral hazard, where the exercise of unverifiable effort by an agent during the project accomplishment may affect the result of the project. This problem also forms the fundamentals of credit risks, which is caused by the challenge of monitoring and information asymmetry between the bank and the borrower, thus creating an avenue for moral hazard (Schmidt-Mohr, 1997 as cited in Poudel, 2018b).

Unless the principal has a system to reward or punish the officer, the rational agent will always say that the project has failed (Border \& Sobel, 1987 as cited in Navajas \& Trivelli, 2007). Therefore, the agent would never repay the principal. The rational principle would predict this outcome, and he would never lend money to the agent. In reality, however, Townsend (1979) as cited in Navajas and Trivelli (2007) assumes that usually possible for the 
principal to find out what the result of the project was. According to this assumption, the principal may incur fixed verification costs, which enable him to find out the exact correct outcome of the project. In contrast, several empirical studies indicate that there are other factors, such as information symmetry, database quality, and staff competence, that determine effective verification (Eva \& Jaroslav, 2012), other than monitoring costs.

The principal-agent theory suggests that as long as the agent repays the loan, the principal is satisfied, and it does not need to verify the outcome of the project. In case of a loan default, the principal imposes the bankruptcy procedure on the agent, in which case the principal takes all results of the project, and the agent is left with nothing. Townsend (1979) as cited in (Hurka, 2017) proves that under this mechanism, the agent has no incentive for moral hazard; therefore, the agent always truthfully announces the outcome of the several projects.

\subsubsection{CAMEL Approach}

The CAMEL rating framework (Barr et al., 2002) is a scheme for on-site assessments of banks. In this scheme, every bank inspected on-site is assessed from five crucial variables, which are referred to as component variables, relating to its activities and performances. These include capital adequacy, asset quality, the efficiency of management, income quality, and liquidity. These parameters represent banking organizations in the world's working performances, economic results, and regulatory compliance. The parts of CAMEL represent the safety and health of the banks completely (Barr et al., 2002). CAMEL is a model based on the ratios used to evaluate banks ' efficiency. The following is described in the various ratios which make up the framework:

Capital adequacy: capital adequacy is an important measure of a banking entity's economic health. The ratio of banks ' capital with their present liabilities and risk-weighted assets is described (Poudel, 2018b). The adequacy of its assets confirmed that the bank has sufficient assets to expand its activities while at the same moment, its net value is sufficient to absorb economic slumps without becoming insolvent (Bothra, 2018a). It is the ratio of time liabilities to the ability of the banks and another risk like credit risk, market risk, as well as operational risk.

Asset Quality: The value of the asset represents the extent of the credit risk in the bank, as a result of its structure and quality of lending, advancements, and investments. Asset quality describes the economic health of banks as a risk to the solvency of economic organizations, particularly banks, from loss of value in the asset. This decreasing asset value is having an adverse effect, as losses are eventually deduced from the capital, which ultimately impacts the bank's income capacity (Gupta, 2014). This structure measures the quality of assets about the level and strength of assets that are not performed, adequate measures, dispersal of assets, etc. The main argument behind the evaluation of asset quality is for non-performance asset (NPA) components to be defined as a proportion of the total assets. This indicates the quality of advances that the bank has granted to generate interest income (Khodaei, Zagherd, \& Barghi, 2017).

Management Efficiency: management efficiency parameters indicate that the Executive Board and senior management are capable of identifying, measuring, monitoring and monitoring bank hazards (Gadhia, 2015). Depending on its risk perception, the management of the bank makes key choices. It sets and achieves vision and objectives for the organization. This parameter is used to assess the effectiveness of leadership to assign a premium to badly managed banks with better quality discounts.

Earning Quality: Earning quality is a vital parameter that determines a bank's capacity to continuously earn and move into the future. The quality of income refers to the sustainability and development of the bank's future income and the Bank's ability to sustain and earn continuously. It is a profitability measure for banks (Khoury \& Salem, 2018). The parameter gains importance as a substantial part of a bank's income is made through fee-based activities like investments, treasury operations, and corporate advisory services, and so on. The quality of earnings of the bank will also aid the bank in executing activities like dividend payment, maintaining an adequate level of capital, taking up growth and diversification strategies, and maintaining a competitive attitude.

Liquidity: To fulfil the demands of the customers; the creditors and the depositors, banks must maintain liquidity in their assets, as the influence of liquidity crisis in banks can adversely impact their financial performance (Misra \& Aspal, 2013). Cash being liquid of every asset gives the full picture of the liquidity of the bank. Banks need to keep sound cash to deposit ratio to ensure that a large volume of cash is not supported, as idle cash does not generate any returns and will subsequently endanger the earnings quality of the bank.

\subsection{Empirical Evidence}

\subsubsection{Credit Risk and Earnings Efficiency}

A study by Boahene et al. (2012) cited in Hurka (2017) used regression analysis (both fixed and random effect models) in bringing to bear the linkage between credit risk and profitability of some selected banks in Ghana. It came out that the credit risk constituents instead have a positive relationship with bank profitability. This implies that, banks in Ghana experience high profitability irrespective of the large credit risk exposure. The author concentrated on the profitability of the banks instead of performance in the banking sector. Profitability within this work only concentrated on the Return on Assets. This is similar to the research made by Kithinji in 2010, and contrary to other studies that projected that credit risk indicators hurt profitability. In a different dimension, Kolapo et al. (2012) used panel data analysis in studying the impact of credit risk on banks performance using ROA as a 
measure for performance. The result concluded that an increase in credit risks or loan losses provision diminishes profitability (ROA), while an increase in total borrowing and advances enhance profitability.

The effect on the profitability of the commercial banks in Nepal from credit risk analysis was reviewed by Poudel (2018). For the period from 2002/03 to 2014/15, data was gathered from 15 commercial banks operating in the Nepalese economy. An important analytical instrument is the Fixed Effect Model (FEM) of the panel information assessment. Commercial banks ' profitability is calculated by equity returns and is reduced by bankbased factors and macroeconomic factors. The results confirmed that credit risk has a significant negative impact on the profitability of commercial banks in Nepal. Also, the solvency ratio, interest spread rate, and inflation have an insignificant adverse effect on profitability. The research concludes that the capital adequacy, total assets, and GDP growth rate of the commercial banks of Nepal have a substantial beneficial impact on profits. Finally, the study concluded that the inter-bank interest rate has an insignificant positive impact on profitability. This study was conducted in Nepal with a different environment from Ghana. Hence there is the possibility that what pertains there might not be applicable in the Ghanaian context.

Kishori and Jeslin (2017) aimed at investigating various factors that influence credit risk and also aimed at studying the impact of credit risk on the profitability of the bank. The secondary data was collected from the annual reports of the State Bank of India for twenty years (1996- 1997 to 2015-2016). The data were analyzed using multiple regression. The result showed that credit risk has a significant, negative impact on profitability. Moreover, the study concluded that the State Bank of India has been facing credit risk due to inefficient credit risk management and hence should minimize the credit risk by reducing the nonperforming assets and managing the leverage properly. The study utilized multiple regression where autocorrelation of the variables can affect the findings. The analysis of the data violated the assumptions of the autocorrelation, which was neglected in this study. To prevent the possibility of this autocorrelation error, the adoption of the linear regression would have been more appropriate.

Noman, Pervin, Chowdhury, and Banna (2015) found the effect of credit risk on the profitability of the banking sectors of Bangladesh. The study used an unbalanced panel data and 172 observations from 18 private commercial banks from 2003 to 2013. The study uses CRMGL, LLRGL, LLRCRM, and CAR as credit risk indicators and ROAA and ROAE and NIM as profitability indicators. Using OLS random effect model, GLS, and system GMM, the study finds a robust negative and significant effect of CRMGL, LLRGL on all profitability pointers. The analysis also finds a negative as well as a significant effect of CAR on ROAE. As an additional analysis, the results reveal that the effect of the implementation of Basel II is significantly positive on NIM but significantly negative on ROAE. The analysis reveals some significant policy implications for increasing profitability and protecting banks from a crisis.

Gizaw et al. (2013) cited in Norman et al. (2015) examined the impact of credit risk on the profitability of commercial banks in Ethiopia. Secondary data was retrieved from 2 sample commercial banks for 12 years from annual reports of these banks. In analyzing the data, a STATA software version 11 was used to compute the descriptive statics and panel data regression model and the outcome was that credit risk determinants; credit risks, loan loss provisions, and capital adequacy have a significant impact on the profitability of commercial banks in Ethiopia. Therefore the researchers concluded the need to stressed strengthening the credit risk management policies to gain better financial standing for commercial banks in a commercial in Ethiopia. The sample selected for this study was two commercial banks which are inadequate. With only two commercial banks selected and used, generalizing the findings give more doubt to the outcome. With this study to be conducted, the researcher intends to select four banks listed in the Ghana Stock Exchange in the Bono East Region.

\subsubsection{Credit Risk and Liquidity}

Khan and Ali (2016) aim at investigating the relationship between liquidity and profitability of commercial banks in Pakistan. The study was to find the nature of the relationship, and the strength of the relationship exists between the variables. Correlation and regression are used respectively to discover the kind of relationship and extent of the relationship between dependent and independent variables. Secondary data was used for analysis that was extracted from the last five years (2008-2014) annual accounts of Habib Bank Limited. After conducting correlation and regression analysis, the study concluded that there as a significant positive relationship between liquidity with the profitability of the banks. The author concentrated on only liquidity and profitability, neglecting the other financial performance indicators. Indicators such as Capital Adequacy, Earnings and Profitability, Management Efficiency, and Asset Quality were lacking. However, this study to be conducted will include all these financial indicators.

The Study on Hakim and Neaime (2002) cited in Gatuhu (2013) on performance and credit risk in banking: A Comparison Study for Egypt and Lebanon" investigates the impact of liquidity, credit and capital on bank profitability in order to shed light on the strength of risk management practices by using the regression model of time series and cross-section data of banking institutions in Lebanon and Egypt during the period (1993-1999). The study expressed the likelihood of borrowers not repaying their loans as promised. Applying right loan policies with a proper assessment of credit risk and determining the appropriate amount of collateral with little 
concentration of investment and adequate training for credit officers are part of sound risk management. Liquidity has a positive relationship with the effectiveness of credit risk management as the higher the liquidity ratio, the more the coverage of its liabilities. The study concluded that capital adequacy has a positive relationship with the effectiveness of credit risk management.

\subsubsection{Credit Risk and Capital Adequacy}

Ogboi and Unuafe (2013) examined the impact of credit risk and capital adequacy ratio on banks' financial performance in Nigeria using time series and cross-sectional data from 2004-2009. Moreover, the panel data model also was used to estimate the impact of loans and advances (LA), non-performing loans (CRM) and capital adequacy $(\mathrm{CA})$ on return on asset (ROA). The findings concluded that credit risk management and capital adequacy ratio have a positive impact on performance, whereas, loans and advances hurt the bank's profitability. The author made use of the time series data but did not check on the assumptions of the series. It is not appropriate to run an inferential analysis without checking for the normality of the data.

Alshatti (2015) examined the impact of credit risk governance on Jordan's economic performance (2005-2013) and chose thirteen commercial banks to convey their views on all Jordanian commercial banks. The results concluded that the Capital Adequacy ratio, Credit interest/Credit facilities, as well as the leverage ratio don't influence the profits of the Jordanian commercial banks as estimated by ROE, suggesting that other variables albeit capital adequacy ratio, credit interest/credit tools and the leverage ratio effect on banks' profitability. The study neglected management efficiency, which is a very relevant indicator of financial performance in the banking sector. This study fills this research gap by including management efficiency and earnings and profitability in the financial measurement process.

Kurawa and Garba (2014) assessed the effect of credit risk management (CRM) on the profitability of two Nigerian banks with a view to discovering the extent to which default rate (DR), cost per loan asset (CLA), and capital adequacy ratio (CAR) influence return on asset (ROA) as a measure of banks' profitability. Data were generated from secondary sources; generally, the annual reports and accounts of quoted banks from 2002 to 2011. Descriptive statistics, correlation, as well as random-effect generalized least square (GLS) regression techniques were utilized as tools of analysis in the study. The findings concluded that CRM, as measured by three independent variables, has a significant positive effect on the profitability of Nigerian banks. The sample selected for this study was inadequate. The study used only banks in the Nigerian Stock Exchange, which is far below the 18 listed banks in the Nigerian economy.

The economic performance of second class commercial banks in Kenya was assessed by Kipruto, Wepukhulu, and Osodo (2017). Based on the report, the research looks at how the capital adequacy ratio affects business banks ' economic performance in Kenya. The study was solely quantitative, and thus, the design of correlation and descriptive research was used. The trial took place in Kenya's 14-second level commercial banks. It gathered economic information from 2013 to 2016, given that CBK and commercial banks ' websites came into force in 2013. After the National Committee for Science, Technology, and Innovation (NACOSTI) obtained authorization and endorsement, the Central Bank of Kenya provided information. A descriptive review was conducted on the data gathered. In this study, it is not suitable to accept descriptive statistics. In this case, the regression model would have been more appropriate since the study was based on the study of the capital adequacy ratio and its impacts on financial performance. The cause (influence used in the study) is best determined using the regression analysis.

\subsubsection{Credit Risk Management and Management Efficiency}

Abdelrahim (2013) investigated the determinants, challenges, and developing means of credit risk management at Saudi Banks. The methodology is descriptive and analytical using the "CAMEL" Model for analyzing the performance of credit risk management. The study concluded that liquidity has a significant strong positive impact besides bank size, which has a significantly strong adverse effect on the effectiveness of credit risk management. In conclusion, the study indicated that while other variables of capital adequacy, asset quality, management soundness, and earning have an insignificant impact on the efficiency of credit risk management. The study evaluated the determinants and the challenges as well as developing means of credit risk management. The study, therefore, neglected the impact that these determinants have on the performance of the banking sector.

The Study of Rani (2009) cited by Kipruto, Wepukhulu and Osodo (2017) on "CAMEL Framework of Risk Management in Indian Banks" emphasized the following determinants of the efficiency of credit risk management: enhancing capital adequacy; strengthening assets quality; improving management soundness; increasing earnings, having adequate liquidity and reducing sensitivity to market risk. The study concluded that the asset turnover ratio, which is a proxy of management soundness, is increasing every year in Indian banks that denote bank efficiency in using assets in generating revenue. This study used the t-test for the analysis of the data. However, studies of this nature which emphasize effect is better evaluated using the inferential analysis such as Regression and Time Series Analysis.

Sheeba (2017) aimed at investigating the influence of Credit risk on the profitability of the bank. Through comprehensive literature review, various factors that influence Credit risk are classified as Capital adequacy ratio 
(CAR), Nonperforming Asset ratio (NPA), Loan to Deposit Ratio (LDR), Cost per Loan Ratio (CLR), Outline Coverage Ratio (PCR), Leverage Ratio (LR), and Nonperforming Asset to Asset Ratio (NPAAR). Return on Equity (ROE) is recognised as an indicator of profitability. The secondary data is solicited from the Annual reports of the State Bank of India for twenty years (1997-2016). The data is analyzed using multiple regression. The result showed that NPAAR alone has a significant negative impact on ROE, and other indicators of credit risk do not have a significant impact on ROE. But overall credit risk has a significant impact on the profitability of State Bank of India. State bank of India bears credit risk due to inefficient Credit risk management. So it is advised to fix Credit risk management practices in State Bank of India. The State Bank of India can minimize Credit risk by reducing the Nonperforming assets by framing strict loan policies.

\section{Methodology \\ 3.1 Type of Research}

This study adopted the explanatory research. The explanatory research focuses on clarifying the relationship between two or more aspects of a situation or phenomenon. It uses inferential analysis to study connections between dimensions or characteristics of individuals, groups, conditions, or events (Nicholas, 2011). This study used the explanatory research because it sought to determine whether there is a significant relationship between credit risk management and capital adequacy, asset quality, management quality, earnings efficiency and liquidity of listed banks in the Ghana Stock Exchange in the Bono East Region of Ghana

\subsection{Population}

The population for this study was the banks on the Ghana Stock Exchange in the Bono East Region. They are Access Bank, ADB, GCB Bank, and Republic Bank. These banks constituted the population because the study involved listed commercial banks on the Ghana Stock Exchange located in the Bono East Region of Ghana. The researcher searched the Ghana Stock Exchange website, and the banks that were listed and located in the Bono East Region were used for the study.

\subsection{Sample and Sampling Technique}

For the sample size, the study used Access Bank, ADB, GCB Bank, and Republic Bank. The study considered these selected banks because they are listed under the Ghana Stock Exchange and operates within the Bono East Region, Techiman. The census sampling technique was used to select the sample banks for the study. In census sampling, all the population constitutes the sample for the study.

\subsection{Data Collection}

\subsubsection{Source of Data collection}

The study used secondary sources of data. The secondary data were obtained from financial statements and annual reports of the banks listed in the Ghana Stock Exchange in the Bono East of Ghana over the period 2009-2015.

\subsubsection{Instrument of Data Collection}

The study used panel data for the research. The panel data is a data collection that deals in two dimensions; a combination of the cross-sectional and time-series data; that is, data is collected overtime on the same sample and estimations are run over these two dimensions. The panel data enables one to describe a change over time as well as the occurrence (non-occurrence) of events in time. Because this study assessed the effect of credit management on financial performance, it was prudent to adopt secondary data from the reports and financial statements of the selected banks.

\subsubsection{Instrument Validity and reliability}

Validity is an important characteristic of research data since important decisions are taken based on the data. Validity is one of the basic principles of research and is the ability to produce in a word, to obtain findings that are in agreement with theoretical or conceptual values, accurate results and measures its supposed constructs (Erickson, 2017). A valid measure produces true results that reflect the true situation and condition of the environment it is supposed to study.

The study sourced data from the Ghana Stock Exchange to ensure the validity of the data that is used for the analysis. Besides, this data was compared to financial statements from the banks' website, the Ghana Banking Survey, and the Financial Statements Holding from PricewaterhouseCoopers. All these were to ensure that the data obtained were valid and reliable for the study.

\subsubsection{Procedure of Data Collection}

For the secondary data, the researcher first visited the websites of the Ghana Stock Exchange and retrieved the financial statements by the five selected banks under study. These reports were also compared with the financial reports from the websites of the banks as well as those published by the PricewaterhouseCoopers. The data were studied carefully to ensure that there were no deviations between what is posted in the Ghana Stock Exchange and the bank itself. 


\subsection{Method of Data Analysis}

The research considered both descriptive and inferential data analysis for the study. The descriptive analysis made use of simple tables and figures were used to present findings of respondents and percentages used to discuss results. The effects of credit risk management on performance, regression, and correlation analysis were employed. Data collected was organized into various categories; a relationship was then established from these categories. The results were tested to see the extent of the relationship using the following linear regression equation model: $\mathrm{Y}=\boldsymbol{\beta 0}+\beta 1 \mathrm{X} 1+\beta 2 \mathrm{X} 2+\beta 3 \mathrm{X3}+\beta 4 \mathrm{X} 4+\beta 5 \mathrm{X} 5+\boldsymbol{\epsilon}$

Where;

$\mathbf{Y}=$ Financial performance of listed banks in the Ghana Stock Exchange in the Bono East of Ghana measured by Return on Assets (ROA)

$\mathbf{X}_{\mathbf{1}}$ the capital adequacy ratio. $\mathbf{X}_{\mathbf{2}}$ the asset quality, $\mathbf{X}_{\mathbf{3}}$ is the management quality, $\mathbf{X}_{\mathbf{4}}$ is the earnings efficiency, $\mathbf{X}_{\mathbf{5}}$ is the liquidity ratio and $€=$ Error term

The $\boldsymbol{\beta}$ coefficient from the equation represented the strength and direction of the relationship between the variables. To apply concluded a more general population with the representative sample size as previously indicated, inferential statistical analysis was also employed. The quantitative data presentation method was used to measure the relationship between the variables to make valid and objective inferences.

\section{RESULTS AND DISCUSSION OF FINDINGS}

\subsection{Data Presentation and Analysis}

\subsubsection{Normality of the Data}

The normality of data was determined, which is a requirement for the regression analysis. The linear regression analysis requires all variables to be multivariate normal. Table 4.1 presents the results from two well-known tests of normality, namely the Kolmogorov-Smirnov Test and the Shapiro-Wilk Test. The decision is that if the Significance value of the Kolmogorov-Smirnov Test is greater than $5 \%$, then the data is said to be usually distributed. If it is below $5 \%$, the data significantly deviate from a normal distribution.

Table 4.1: Tests of Normality

\begin{tabular}{lcccccc}
\hline & \multicolumn{3}{c}{ Kolmogorov-Smirnov $^{\mathrm{a}}$} & \multicolumn{3}{c}{ Shapiro-Wilk } \\
& Statistic & $\mathrm{df}$ & Sig. & Statistic & df & Sig. \\
\hline CRM & 0.287 & 113 & $0.310^{*}$ & 0.807 & 113 & 0.762 \\
CAR & 0.177 & 113 & $0.200^{*}$ & 0.964 & 113 & 0.827 \\
AQ & 0.166 & 113 & $0.214^{*}$ & 0.814 & 113 & 0.823 \\
MQ & 0.151 & 113 & $0.218^{*}$ & 0.713 & 113 & 0.793 \\
IP & 0.123 & 113 & $0.232^{*}$ & 0.923 & 113 & 0.832 \\
LR & 0.387 & 113 & $0.330^{*}$ & 0.337 & 113 & 0.332 \\
\hline
\end{tabular}

Source, Field Data (2019)

Key: $C R M=$ credit risk management $C a r=$ Capital Adequacy Ratio, $A Q=$ Asset Quality, $M Q=$ Management Quality, EnP = Earnings and Profitability, LR = Liquidity Ratio

The results indicate that the data passes the test for normality confirming the multivariate normality of the data. This because the Kolmogorov-Smirnov Test values for the variables are all greater than the $5 \%$ significance level.

\subsubsection{Preliminary Analysis of the various Variables}

The study calculated the descriptive and correlations of the variables. The correlation was to determine the relationship between the variables under investigation. The descriptive table is indicated in Table 4.2.

Table 4.2: Descriptive of the Variables

\begin{tabular}{lcc}
\hline Variable & Mean & Standard Deviation \\
\hline CRM & 19.05 & 1.52 \\
AQ & 8.063 & 2.507 \\
MQ & 4.435 & 2.554 \\
CAR & 14.596 & 0.777 \\
IP & 6.876 & 1.581 \\
LR & 13.695 & 2.117 \\
\hline
\end{tabular}

Source: Field Survey (2019)

From Table 4.2, the mean value of the CRM was 19.05, and a standard deviation of 1.52. Compared to the global standard below 5\% of the CRM ratio, it is not mistaken to say that the CRM ratio of the banks chosen is now alarming and demands immediate, credible and lasting action in resolving it. For example, the highest proportion of the banks' loans went to private enterprises with their share of the total increasing from 77.3 per cent in July 2015 to 78.8 per cent in July 2016.

The selected banks ' Capital Adequacy ratio was 14.596, with a standard deviation of 0.777 . With the main solvency indicator, the bank sector remained solvent, and the CAR remained well above the statutory requirement 
of the $10 \%$ minimum requirement of the Banking Act (Act 673). This implies that Access Bank, Agricultural Development Bank, GCB Bank, and Republic Bank were able to comply with the law and thus remained capitalized. Also, it implies that the selected banks remain adequately liquid to meet their short-term obligations.

The asset quality of the banks registered a mean value of 8.063 and a standard deviation of 2.507. This is not surprising since the ratio of banks reported by the BoG indicated that total loans were classified as impaired and this remained high till 2015. In June 2018, the CRM ratio decreased to 22.6\% compared with the latest recorded 23.5\% ratio in April 2018. On the other side, over the same relative period, the percentage of impaired government sector assets improved from 5.1 to 10.1

$\%$. From a Loan Portfolio, Securities and Derivatives viewpoint, asset quality has remained a significant problem for most of Ghana's banks.

The MQ was $4.435 \%$ and a standard deviation of 2.554 . The MQ of the banks is, therefore $4.435 \%$ and this percentage were not good for the banks. About banks ' leadership measure, it is fascinating to note that most banks have a well-constituted board of directors that have a clear division of responsibility at the top hierarchy of the banks as a follow-up to the Corporate Governance Guidelines published in December of 2018. Most banks have a distinct succession plan, independent auditors, main management supervision, the appointment of management, and tenors of management to further encourage a sound corporate culture. All this was set up to restore the trust in banks' executives.

The earnings and profitability of the Access Bank, Agricultural Development Bank, GCB Bank, and Republic Bank was at 6.876 with a standard deviation of od 1.581 . The earnings and profitability of the selected banks were low. This could be due to the significant reduction in the growth rate of net interest income, coupled with an increase in the growth rate of provisions on non-performing loans. According to the Bank of Ghana 2018 report, interest income contracted by 9.2 per cent year on year in April 2018 compared with a 29.2 per cent growth in April 2017. This was due to a reduction in interest income on outstanding loans, (partly due to the increasing stock of banks' non-performing loans some of which have interest charges on their accounts frozen), as well as a contraction in interest income on investments attributed mainly to the declining yields on money market instruments. This could, therefore, account for the reduced earnings and profitability within the selected banks. Also, the increase in the stock of CRMs during the period under review led to an increase in provisions with further adverse implications on the profit and loss statement of the banks.

Liquidity inspires depositor and lender confidence. Illiquidity, rather than poor asset quality is the immediate cause of a bank's failure. The study indicates that the liquidity ratio was 9.695, with a standard deviation of 2.117. The sector remained solvent with improved liquidity and Liquidity Coverage Ratios (LCR). For instance, GCB was ranked first with customer deposits of about Ghs 8.1 bn with a $9.695 \%$ year on year growth. The banks, therefore, were generally illiquid as they registered liquidity of $9.695 \%$, which is less than the $10.4 \%$ requirement set by the Bank of Ghana. The Bank of Ghana, in its regulations, set the minimum liquidity of banks to $11 \%$ in April 2014 but later reduced it to $10.6 \%$ and $10.4 \%$ in 2014 and 2015 respectively.

The correlation table and its interpretations are shown below in Table 4.3.

Table 4.3: Correlation Analysis of the Variables

\begin{tabular}{lllllll}
\hline & CRM & AQ & MQ & CAR & EnP & LR \\
\hline CRM & 1.00 & & & & & \\
AQ & $-0.394^{* *}$ & 1.00 & & & & \\
MQ & $-0.481^{* *}$ & $0.178^{* *}$ & 1.00 & & & \\
CAR & $-0.364^{* *}$ & $0.386^{* *}$ & $0.266^{* *}$ & 1.00 & & \\
EnP & $-0.496^{* *}$ & $0.388^{* *}$ & $0.361^{* *}$ & $0.441^{* *}$ & 1.00 & \\
LR & $-0.2616^{* *}$ & $-0.321^{* *}$ & 0.4256 & -0.134 & -0.189 & 1.00 \\
\hline
\end{tabular}

Source: Field Survey (2019)

**. Correlation is significant at the 0.05 significant level (2-tailed)

Results from the study indicated in Table 4.3 shows that there is a negative relationship between the variable under investigation. AQ correlated negatively with CRM of banks with a correlated value of -0.394 and significant at 0.05 margin of error. The implication is that AQ and CRM of banks are inversely related, and an increase in CRM leads to a reduction of asset quality of the banks. Similarly, MQ inversely relates CRM of banks with MQ registering a greater correlated value (r-value of -0.481 and $p$-value $<0.05$ ) than AQ (r-value of -0.394 and $p$-value $<0.05$ ). This implies that, though MQ and AQ inversely relate CRM of banks, an increase in MQ decreases CRM of banks than AQ. There is also, a negative correlation between EnP and CRM of banks with a Pearson correlation value of -0.496 and a significance value less than 0.05 . This implies that an increase in CRM of banks will lead to a reduction of earnings and profitability.

Additional, the results indicated that CRM negatively correlated with liquidity in the banking sector. The liquidity ratio registered a correlation value of -0.2616 and significant and also significant at the $5 \%$ level of significance. 
4.1.3 The Impact of Credit Risk Management (CRM) on Capital Adequacy Ratio (CAR)

The ANOVA table for the regression analysis is indicated in Table 4.4

Table 4.4: ANOVA on CAR and Liquidity of banks

\begin{tabular}{llccccc}
\hline Model & & Sum of Squares & Df & Mean squares & F & Sig. \\
\hline 1 & Regression & 5.186 & 1 & 5.186 & 16.430 & $0.000^{\mathrm{b}}$ \\
& Residual & 9.784 & 29 & 0.316 & & \\
& Total & 14.970 & 30 & & & \\
\hline
\end{tabular}

a. Dependent Variable: CRM; b. Predictors: (Constant), CAR

Source: Field Data (2019)

The p-value or level of significance is 0.000 indicated in Table 4.4 illustrates that the available data was a good fit for the model. This implies that there is strong evidence that the regression model gives accurate predictions on the relationship between CAR and CRM.

The regression model summary showing the correlation coefficient ${ }^{\circledR}$ and the coefficient of determination (R-square) is presented in Table 4.5.

Table 4.5: Regression Model Summary

\begin{tabular}{lllll}
\hline Model & R & R Square & Adjusted R Square & Std. Error \\
\hline 1 & -0.364 & 0.246 & 0.245 & 0.562
\end{tabular}

\section{(Source: Field Data, 2019)}

The correlation coefficient of the model summary was -0.364 , as indicated in Table 6 . This illustrates that there is a positive correlation between CRM and CAR. The coefficient of determination (R squared) is 0.246 , indicating that the independent variable (CRM) accounted for a reduction of $24.6 \%$ of the cause of variation in the dependent variable CAR.

To determine the predictive effect of the independent variable (CRM) on the dependent variable (CAR), the regression coefficients were used, as indicated in Table 4.6.

Table 4.6: Regression Coefficients of CAR and Liquidity of banks

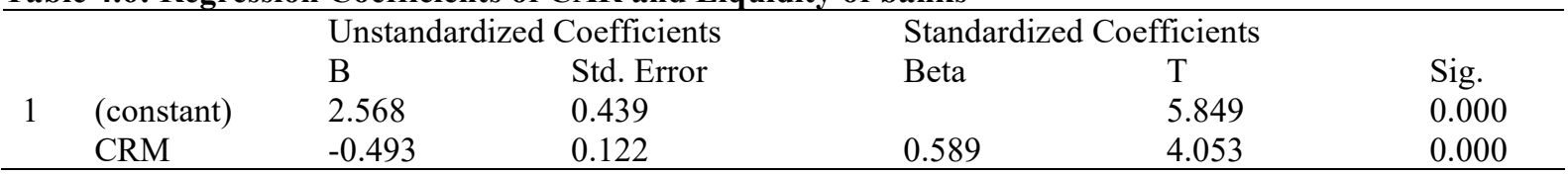

a. Dependent variable: CAR

The regression coefficients illustrated in Table 4.6 showed a constant of 2.568 and a regression coefficient of -0.493 concerning CRM. The equation is:

$\mathrm{CAR}=2.568-0.493(\mathrm{CRM})$

The regression model indicates that a unit increase in CRM will lead to a 0.493 decrease in CAR. There is, therefore, a negative effect of CRM and CAR of banks as illustrated by the regression coefficient of -0.493 .

4.1.4 The impact of Credit Risk Management on Asset Quality of Banks

The ANOVA table for the regression analysis is indicated in Table 4.7

Table 4.7: ANOVA on CRM and Asset Quality

\begin{tabular}{llccccc}
\hline Model & & Sum of Squares & Df & Mean squares & F & Sig. \\
\hline 1 & Regression & 4.531 & 1 & 8.042 & 7.155 & $0.000^{\mathrm{b}}$ \\
& Residual & 36.438 & 29 & 1.124 & & \\
& Total & 40.970 & 30 & & & \\
\hline
\end{tabular}

a. Dependent Variable: Asset Quality; b. Predictors: (Constant), CRM

Source: Field Data (2019)

From Table 4.7, the processed data had a significance level of 0.00 which shows that the data is ideal for making any conclusion on the CRM and Asset Quality of banks as the value of significance ( $p$-value) is less than $5 \%$. This implies that there is enough evidence that the regression model gave accurate predictions on the relationship between CRM and asset quality.

Table 4.8: Regression of CRM and Asset Quality

\begin{tabular}{lllll}
\hline Model & R & R Square & Adjusted R Square & Std. Error \\
\hline 1 & -0.481 & 0.141 & 0.142 & 0.1012
\end{tabular}

Source: Field Data (2019)

The results from Table 4.8 indicates that a negative relationship exists between CRM and the asset quality of banks. The negative correlation between the CRM and asset quality indicated that as CRM increases, there is the likelihood of a corresponding decrease in asset quality. Predictably, CRM negatively predicts asset quality $14.1 \%$ (from the r-square value of 0.141 ).

To determine the predictive effect of the independent variable (CRM) on the dependent variable (Asset Quality), the regression coefficients were used, as indicated in Table 4.9. 
Table 4.9: Regression Coefficients of CRM and Asset Quality

\begin{tabular}{lllllll}
\hline & & \multicolumn{2}{l}{ Unstandardized Coefficients } & \multicolumn{2}{l}{ Standardized Coefficients } & Sig. \\
\hline & & B & Std. Error & Beta & T & 6.533 \\
& (constant) & 2.906 & 0.445 & & 0.000 \\
& CRM & -0.407 & 0.156 & 0.333 & 1.963 & 0.041 \\
\hline
\end{tabular}

b. Dependent variable: Asset Quality

The regression coefficients illustrated in Table 4.9 showed a constant of 2.906 and a regression coefficient of -0.407 concerning asset quality. The equation represents this:

Asset Quality $=2.906-0.407(\mathrm{CRM})$

The regression model indicates that a unit increase in CRM will lead to a 0.407 decrease in the asset quality of the selected banks. There is, therefore, a negative effect of CRM and asset quality of banks as illustrated by the regression coefficient of -0.407 .

\subsubsection{The Impact of Credit Risk Management on Management Quality}

To analyze the influence and predictive capacity of CRM on the management quality of banks, the study adopted the simple regression for the analysis. The ANOVA table for the regression analysis is indicated in Table 4.10

Table 4.10: ANOVA on CRM and Management Quality

\begin{tabular}{llccccc}
\hline Model & & Sum of Squares & Df & Mean squares & F & Sig. \\
\hline 1 & Regression & 1.965 & 1 & 1.965 & 4.683 & $0.008^{\mathrm{b}}$ \\
& Residual & 13.005 & 29 & 0.420 & & \\
& Total & 14.970 & 30 & & & \\
\hline
\end{tabular}

a. Dependent Variable: Management Quality; b. Predictors: (Constant), CRM Source: Field Data (2019)

From Table 4.10, the p-value helps to determine whether the condition means were relatively the same or if they were significantly different from one another.

The model summary of the CRM as the independent variable against management quality as the dependent variable is indicated in Table 4.11

Table 4.11: Model Summary of CRM and Management Quality

\begin{tabular}{lllll}
\hline Model & R & R Square & Adjusted R Square & Std. Error \\
\hline 1 & -0.387 & 0.119 & 0.1533 & 0.5518 \\
\hline
\end{tabular}

Source: Field Survey (2019)

The positive R-value is an indication of a negative correlation between the variables. It can, therefore, be concluded that there is a negative relationship between CRM and management quality. The R-square value of 0.119 means that $11.9 \%$ of the variation in CRM negatively predicts management quality. From these results, the standard error is 0.5518 , which implies that the model gives a better prediction of the outcomes.

Therefore, the results show that the overall model was significant and that the CRM predicted management quality negatively. Thus, there is a negative relationship between CRM and management quality. Conclusively, the study reveals that an increase in CRM within the institution negatively predicts $11.9 \%$ of management quality.

To determine the predictive effect of the independent variable (CRM) on the dependent variable (management quality), the regression coefficients were used, as indicated in Table 4.12.

Table 4.12: Regression Coefficients of AM and Liquidity of banks

\begin{tabular}{lllllll}
\hline & & \multicolumn{2}{l}{ Unstandardized Coefficients } & \multicolumn{2}{l}{ Standardized Coefficients } \\
Model & & B & Std. Error & Beta & t & Sig. \\
\hline 1 & (constant) & 3.622 & 0.334 & & 10.838 & 0.000 \\
& CRM & -0.214 & 0.099 & 0.362 & 2.164 & 0.038 \\
\hline
\end{tabular}

c. Dependent variable: management quality

The regression coefficients illustrated in Table 4.12 showed a constant of 3.622 and a regression coefficient of -0.214 concerning management quality. The equation represents this:

Management Quality = 3.622 - $0.214(\mathrm{CRM})$

The regression model indicates that a unit increase in CRM will lead to a 0.214 decrease in management quality of banks. There is, therefore, a negative effect of CRM and management quality as illustrated by the regression coefficient of -0.214 .

4.1.6 The impact of Credit Risk Management and Earnings and Profitability.

The ANOVA table for the regression analysis is indicated in Table 4.13 
Table 4.13: ANOVA on CRM and Earnings and Profitability

\begin{tabular}{llccccc}
\hline Model & & Sum of Squares & Df & Mean squares & F & Sig. \\
\hline 1 & Regression & 10.825 & 1 & 10.825 & 11.132 & $0.000^{\mathrm{b}}$ \\
& Residual & 30.145 & 89 & 0.972 & & \\
& Total & 40.970 & 90 & & & \\
\hline
\end{tabular}

a. Dependent Variable: Earnings and Profitability; b. Predictors: (Constant), CRM

Source: Field Data (2019)

The p-value or level of significance is 0.000 indicated in Table 4.13 illustrates that the available data was a good fit for the model. This implies that there is strong evidence that the regression model gives accurate predictions on the relationship between CRM and earnings and profitability in the banking sector.

A summary of the independent variable (CRM) and Earnings and Profitability) in the banking sector as the dependent variable is shown in Table 4.14

Table 4.14: Model Summary of the Regression

\begin{tabular}{lllll}
\hline Model & R & R Square & Adjusted R Square & Std. Error \\
\hline 1 & -0.515 & 0.365 & 0.298 & 0.1232
\end{tabular}

Source: Field Survey (2019)

The negative $\mathrm{R}$-value is an indication that there is a negative relation between CRM and earning and profitability of the selected banks. The R-Square value of 0.365 means that $36.5 \%$ of the variation in CRM is explained by the fitted line, together with the Liquidity of banks. From these results, the standard error is 0.1232 , which implies that the model gives a better prediction of the outcomes.

To determine the predictive effect of CRM on earnings and profitability, the regression coefficients were used, as indicated in Table 4.15.

Table 4.15: Regression Coefficients of CRM and Earnings and Profitability

\begin{tabular}{llllll} 
& \multicolumn{2}{l}{ Unstandardized Coefficients } & \multicolumn{2}{l}{ Standardized Coefficients } & Sig. \\
& B & Std. Error & Beta & 4.790 & 0.003 \\
(constant) & 1.314 & 0.734 & & 3.336 & 0.002 \\
\hline
\end{tabular}

d. Dependent variable: earnings and profitability

The regression coefficients illustrated in Table 16 showed a constant of 1.314 and a regression coefficient of -0.419 concerning CRM and earnings and profitability. The estimated coefficients were significant at the $5 \%$ level. This is represented by the equation:

Earnings and Profitability $=1.314-0.419(C R M)$

The regression model indicates that a unit increase in CRM will lead to a 0.419 decrease in earnings and profitability. There is, therefore, a negative effect of CRM on earnings and profitability, as illustrated by the regression equation.

4.1.7 The impact of Credit Risk Management and Liquidity of Banks.

The ANOVA table for the regression analysis is indicated in Table 4.16

Table 4.16: ANOVA on CRM and Liquidity of Banks

\begin{tabular}{llccccc}
\hline Model & & Sum of Squares & df & Mean squares & F & Sig. \\
\hline 1 & Regression & 11.815 & 1 & 2.3017 & 10.857 & $0.000^{\mathrm{b}}$ \\
& Residual & 27.195 & 89 & 0.212 & & \\
& Total & 39.01 & 90 & & & \\
\hline
\end{tabular}

b. Dependent Variable: Liquidity of Banks; b. Predictors: (Constant), CRM

Source: Field Data (2019)

The p-value or level of significance is 0.000 indicated in Table 4.16 illustrates that the available data was a good fit for the model. This implies that there is strong evidence that the regression model gives accurate predictions on the relationship between CRM and Liquidity in the banking sector.

A summary of the independent variable (CRM) and liquidity in the banking sector as the dependent variable is shown in Table 4.17

Table 4.17: Model Summary of the Regression

\begin{tabular}{lllll}
\hline Model & R & R Square & Adjusted R Square & Std. Error \\
\hline 1 & -0.217 & 0.161 & 0.191 & 0.0212 \\
\hline
\end{tabular}

Source: Field Survey (2019)

The negative R-value is an indication that there is a negative relation between CRM and Liquidity of the selected banks. The R-Square value of 0.161 means that $16.1 \%$ of the variation in liquidity is explained by CRM. From these results, the standard error is 0.0212 , which implies that the model gives a better prediction of the outcomes. The regression coefficients are indicated in Table 4.18. 
Table 4.18: Regression Coefficients of CRM and Liquidity of Banks

\begin{tabular}{llllll}
\hline & \multicolumn{2}{l}{ Unstandardized Coefficients } & \multicolumn{2}{l}{ Standardized Coefficients } \\
& $\mathrm{B}$ & Std. Error & Beta & $\mathrm{T}$ & Sig. \\
\hline (constant) & 1.001 & 0.234 & & 5.090 & 0.000 \\
CRM & -0.119 & 0.056 & 0.114 & 4.345 & 0.000 \\
\hline
\end{tabular}

e. Dependent variable: Liquidity of Banks

The regression coefficients illustrated in Table 4.15 showed a constant of 1.314 and a regression coefficient of -0.119 in respect to the Liquidity of the selected banks. This is represented by the equation: Liquidity $=1.001-0.119(C R M)$

The regression model indicates that a unit increase in CRM will lead to a 0.119 decrease in liquidity. There is, therefore, a negative effect of CRM on liquidity as illustrated by the regression equation.

\subsection{Discussion of Findings}

\subsubsection{Research Objective One: The impact of Credit Risk Management (CRM) on Capital Adequacy Ratio (CAR)}

There was strong evidence that the regression model gave accurate predictions on the relationship between credit risk management and CAR. There is a positive correlation between CRM and CAR, such that CRM accounted for a reduction of $24.6 \%$ of the cause of variation in the dependent variable CAR. This provides evidence that as the CRM of the bank increases, it worsens the liquidity and subsequently, the CAR. This is because CAR provides the number of own funds accessible to support the bank and act as a cushion against any adverse conditions. Therefore, an increase in CRM reduces with adequate bank capital. A well-capitalized bank faces a lower risk of going bankrupt and hence offers safety for depositors in times of adverse macroeconomic conditions. Capital adequacy increases the strength of the bank, which improves the solvency of the bank and the capacity to absorb the loan loss and protect the bank from bankruptcy. Alshatti (2015) has asserted that the capital adequacy ratio is affected by CRM in the banking sector. Also, according to Epure and Lafuente (2015), performance has an inverse relationship with nonperforming loans and capital adequacy related positively with performance. Muritala and Taiwo (2016) assert that loans are the largest and most obvious source of credit risk, while others are found on the various activities that the bank involved itself with.

4.2.2 Research Objective two (2) : The Impact of credit risk management and the asset quality of banks, CRM negatively relates to asset quality with a coefficient of -0.481 . This value is significant; hence, CRM negatively predicts the asset quality by -0.481 . The concept is that if no one ever defaulted and was without any credit risk, then the bank will have enough credit to cushion itself in terms of troubles. On the one hand, higher default risk raises the holding costs and thus, the liquidity discount of corporate bonds. Berger and Bouwman (2005) indicated that an important activity for banks is given loans to firms because about half of the liquidity they create is done via loan commitments. Therefore an increase in CRM impairs the bank and makes it incapable of supporting other firms and itself. An indicator shows that the higher the ratio, the poorer the quality, and therefore the higher the risk of the loan portfolio will be (Mumbi \& Omagwa, 2017). Assessing the impact of loan activities on bank risk, Ofosu-Hene and Amoh (2016) used the ratio of bank loans to assets (LTA). The reason to do so is that bank loans are relatively illiquid and subject to higher default risk than other bank assets, implying a positive relationship between LTA and the risk measures

\subsubsection{Research Objective Three: The Impact of Credit Risk Management on Management Quality}

The results revealed that CRM correlated negatively with the management quality of banks with a correlated value of -0.384 and significant at 0.05 margin of error. The implication is that CRM and management quality are inversely related, and an improvement in CRM tends to affect the management quality of banks negatively. This implies that the banks invest in credit facilities that are risky and thus yield higher interest. Part of credit risks arises when financial institutions' boards or management cannot oversee various units to ensure that they appropriately comply with the policy (Bhardwaj, 2013). Management of financial institutions is responsible for the approval and formation of credit risk (Chaplinska, 2012). Also, they are responsible for reviewing strategies of the bank including delineating bank's overall risk tolerance about credit risk, ensuring that bank's overall credit risk exposure is maintained at prudent levels and consistent with the available capital (Kurawa \& Garba, 2014). The study also ensure that top management, as well as individuals responsible for credit risk management, have sound skills and experience to fulfil the role of risk management, ensuring that the bank follows sound fundamental principles as well as limitations of lending facilities (Muritala \& Taiwo, 2016). They also ensure that suitable credit risk management plans and processes are in place. Consequently, effective credit risk management needs the management and the management to comprehend and regulate the risk profile and loan culture of the bank. To do this, you must know the structure and the hazards involved in the portfolio thoroughly. You must comprehend the product combination, industrial and geographic levels, average risk ratings and other aggregate properties of the portfolio (Maino \& Tintchev, 2012). 


\subsubsection{Research Objective Four: The Relationship between Credit Risk Management and Earnings and Profitability}

The sign of the coefficient of CRM on earnings and profitability was negative and significant. With a coefficient of -0.515 , a unit increase in CRM will decrease earnings and profitability in the banking sector by 0.515 . Wenner, Navajas, Trivelli, and Tarazona (2007) spells out that CRM enables financial institutions to become viable and attain sustainable growth, leads to solvency and reduces costs and improve profit margins. Odonkor (2018) also identifies that reduce earnings volatility, avoidance of losses acts as a decision aid to bankers, better risk-return, avoidance of pitfalls like credit concentrations, lack of credit discipline, aggressive underwriting to high-risk counterparts and products at inadequate prices.

\subsubsection{Research Objective Five: The Relationship between Credit Risk Management and Liquidity}

The model provided a positive relationship between the banking sector and CRM, explaining the liquidity fluctuation of $16.1 \%$. This means that a developer in CRM will result in a decrease in liquidity within the selected banks. The results are consistent with previous findings. For example, Ofosu-Hene and Amoh (2016) found similar results and called for an improvement in the CRM ratio in the banking sector. An increase in CRM shows that they cannot meet up with demand if customers turn up, and thus crisis can develop (Wenner et al., 2007b). Nguyen (2016) defined a liquidity threat as the chance that a bank may not be able to fulfil its commitments towards its depositors and provide borrowers with sufficient resources to carry out lucrative securities trading operations by instantly converting assets into liquid assets, with minimum losses, with the capability to borrow funds where necessary, at the same moment.

\subsection{SUMMARY, CONCLUSION AND RECOMMENDATIONS}

\subsection{Summary}

The study seeks to explore the effect of credit risk management and its relationship to financial performance in the Ghanaian banking sector. The study was conducted due to the loss of confidence of Ghanaians in the financial sector on the severe insolvency and liquidity bank challenges over the years, with constant clearing deficits (BoG, 2017). It is, therefore, urgent to further delve into the situation to raise awareness through empirical evidence on credit risk management and its implications on banks' financial performance. The included in Access Bank, Agricultural Development Bank, Ghana Commercial Bank, and Republic Bank. This study was explanatory employing quantitative methods of data collection. In this research, the four (4) banks were selected with a purpose sampling. The data for this research were secondary collected from the annual audited report and the Ghana Banking Survey. The study adopted the regression analysis model as the model specification for this study.

Objective one of the study sought to determine if there is a significant relationship between credit risk management and capital adequacy. It was found that CAR negatively related to CRM such that CRM accounted for a reduction of $24.6 \%$ of the cause of variation in the dependent variable CAR. This provides evidence that as the CRM of the bank increases, it worsens the liquidity and subsequently, the CAR. This is because CAR provides the number of own funds accessible to support the bank and act as a cushion against any adverse conditions. Therefore, an increase in CRM reduces with adequate bank capital.

Objective two sought to determine if there is a significant relationship between credit risk management and the asset quality of banks. The results indicated that CRM negatively relates to asset quality with a coefficient of -0.481 . This value is significant; hence, CRM negatively predicts the asset quality by -0.481 . The concept is that if no one ever defaulted and was without any credit risk, then the bank will have enough credit to cushion itself in terms of troubles.

Objective three sought to determine if there is a significant relationship between credit risk management and management quality of banks in Ghana. The results revealed that CRM correlated negatively with the management quality of banks with a correlated value of -0.384 and significant at 0.05 margin of error. The implication is that CRM and management quality are inversely related, and an improvement in CRM tends to affect the management quality of banks negatively.

Objective four also determine if there is a significant relationship between credit risk management and an earnings efficiency of banks in Ghana. An outcome of the results indicated that CRM related negatively with earnings and profitability. The sign of the coefficient of CRM on earnings and profitability was negative and significant. With a coefficient of -0.515 , a unit increase in CRM will decrease earnings and profitability in the banking sector by 0.515 .

Objective five sought to determine if there is a significant relationship between credit risk management and the liquidity of banks in Ghana. The study revealed strong evidence that the regression model gives accurate predictions on the negative relationship between CRM and Liquidity in the banking sector, such that $16.1 \%$ of the variation in liquidity is explained by CRM. This means that an increase in CRM will result in a decrease in liquidity within the selected banks. 


\subsection{Conclusion}

The study concludes that CRM has a negative relationship with performance in the banking sector. Specifically, CRM related negatively with capital adequacy ratio, asset quality, management quality, earnings and profitability, and liquidity. The concept is that an increase in CRM means bad credit risk management and vice versa. The implication, therefore, is that an increase in credit risk management gives rise to an increase in performance.

\subsection{Recommendations}

It was found out that the CRM decreased the performance of the banking sector. It is therefore recommended that training programs be organized for credit officers on effective client monitoring. For the customers, there is the need to design and implement adequate loan management programs to educate clients on proper management of loans. The policy and procedures should be living documents that reflect current and emerging credit practices. Furthermore, CRM has been discovered to be negative for asset quality. The Management Board and the Board should, therefore, monitor and assess its credit strategies continuously to ensure that lending operations of the bank are carried out in a safe and sound way and line with strategic goals, present business procedures, and financial circumstances.

It was also discovered that the CRM had a negative correlation with the quality of the leadership of banks. Management should, therefore, use the services of skilled and skilled staff in the banking sector. This will ensure that decisions concerning delineating the bank's overall risk tolerance are reviewed about prudent credit risk policies.

Furthermore, it was found that CRM related negatively with earnings and profitability. It is therefore recommended that banks adopt proper credit risk management strategies since effective credit management enables financial institutions to become viable and attain sustainable growth and improve profit margins.

5.4 Suggestions for further research

The study was limited to selected banks on the Ghana stock exchange which operates within the Bono East Region, Techiman. It is therefore recommended that further studies be undertaken to cover more banks to either confirm or refute these findings.

\section{REFERENCES}

Abayomi, O., \& Daniel, S. (2011). Credit Risk Management and Interest Income of Banks in, (2007), 23-35.

Abdelrahim, K. (2013). Effectiveness of Credit Risk Management of Saudi Banks in the Light of Global Financial Crisis: A Qualitative Study. Asian Transactions on Basic and Applied Sciences, 03(02), 2221-4291.

Adarkwa, R. (2011). Risk Management and Bank Performance. A Case Study of First Atlantic Merchant Bank Ghana Limited (FAMBL). Financial Markets, Institutions and Instruments, 17(6), 76-93.

Afriyie, H. O., \& Akotey, J. O. (2013). Credit Risk Management and Profitability of selected Rural Banks. Catholic University College of Ghana.

Agyei, S. (2017). Credit Risk and Profitability of Selected Banks in Ghana Credit Risk and Profitability of Selected Banks in Ghana. Research Journal of Finance and Accounting, 3(7), 2222-2847.

Agyiri, B. K. (2012). The Role of Board of Directors and Management in Effective. Kwame Nkrumah University of Science and Technology, Kumasi - Ghana.

Ahmadyan, A. (2018). Measuring Credit Risk Management and its Impact on Bank Performance in Iran. Marketing and Branding Research, 5, 168-183.

Alshatti, A. S. (2015). The effect of credit risk management on financial performance of the Jordanian commercial banks. Investment Management and Financial Innovations, 12(1-2), 338-345.

Asante, Y. A. (2015). Assessing Credit Management Practices in Savings \& Loans Companies : A Case Study of First Allied Savings \& Loans Ltd. Kwame Nkrumah University of Science and Technology: Kumasi, Ghana. Retrieved from http://ir.knust.edu.gh/bitstream/123456789/8499/1/

Badu, A. N. Y. (2012). An assessment of the effectiveness of credit risk management tools utilized by financial institutions in Ghana, 1-59.

Basel Committee. (1999). Principle for the Management of Credit Risk-Consultative Paper issued by the Basel Committee on Banking Supervision (Vol. 54). Washington, D.C. Retrieved from https://www.bis.org/publ/bcbs54.pdf

Bhardwaj, T. (2013). CREDIT RISK MANAGEMENT PRACTICES : A COMPARATIVE STUDY OF STATE BANK OF INDIA AND PUNJAB NATIONAL BANK Research Project Report in partial fulfillment of the requirements ( Minor Subject : Economics ) School of Business Studies College of Basic Sciences an.

Bhattarai, B. P. (2018). Impact of Bank Specific and Macroeconomic Variables on the Performance of Commercial Banks of Nepal. Global Review of Accounting and Finance, 9(1), 35-53.

Binks, M. R., \& Ennew, C. T. (1997). The relationship between U.K. banks and their small business customers. Small Business Economics, 9(2), 167-178.

Blanch, J. (2011). Financial Innovations and their role in the modern financial systems - Identitication and 
systematization of the problem. Financial Internet Quarterly "e-Finanse," 7(3), 13-26.

Boateng, G. O. (2017). Credit risk management practices of Amantin and Kasei Community Bank. University of Cape Coast.

BoG. (2017a). Bank of Ghana Banking Sector Report Vol. 2.2. Banking Sector Report, 2(2). Retrieved from https://www.bog.gov.gh/privatecontent/

BoG. (2017b). GCB Bank takes over UT bank and Capital Bank Report. Bank of Ghana, 1-4. Retrieved from https://www.bog.gov.gh/privatecontent/.pdf

Bothra, P. (2018a). A Camel Model Analysis of Selected Public and and private sector banks in India. International Journal of Management and Applied Science, 4(3), 1-9.

Bothra, P. (2018b). A camel model of analysis of selected public and private sector banks in India. International Journal of Management and Applied Science, 4(3), 1-9.

Boye, A., \& Kwabena, M. (2014). Credit Risk Management in Financial Institutions: A Case Study of Ghana Commercial Bank Limited. Research Journal of Finance and Accounting, 5(23), 2222-2847.

Chaplinska, A. (2012). Evaluation of the borrower's creditworthiness as an important condition for enhancing the effectiveness of lending operations. Journal for International Business and Entrepreneurship Development, 2(2), 9, 1-11.

Chen, K.-C., \& Pan, C.-Y. (2012). An Empirical Study of Credit Risk Efficiency of Banking Industry in Taiwan. Web Journal of Chinese Management Review, 15(2012), 1-17

Coast, C. (2017). (C) University of Cape Coast https://erl.ucc.edu.gh/jspui, (July).

Ennew, C. T., \& Binks, M. R. (1995). The Provision of Finance to Small Businesses: Does the Banking Relationship Constrain Performance. The Journal of Small Business Finance, 4(1), 57-73.

Epure, M., \& Lafuente, E. (2015). Monitoring bank performance in the presence of risk. Journal of Productivity Analysis, 44(3), 265-281.

Erickson, G. (2017). Causal research design. New Methods of Market Research and Analysis, 1(3), 78-105.

Ferrouhi, E. M. (2017). Moroccan banks analysis using CAMEL model. International Journal of Economics and Financial Issues, 4(3), 622-627.

Gadhia, N. M. (2015). CAMEL Model , A Conceptual Framework For Financial Performance Evaluation Of Banks In India. International Journal of Scientific Research, 4(1), 2277-8179.

Gatuhu, R. (2013). The Effect of Credit Managementon the Financial Performance of Microfinance Institutions in Kenya. International Journal of Business and Social Research, 2(2), 3-5.

Gaughan, P. A. (2010). Mergers, acquisitions, and corporate restructurings. John Wiley \& Sons.

Gladys, B. Y. K. G. (2012). the Effect of Credit Risk Management Practices on. International Journal of Economics, Commerce and Management, 4(11), 612-632.

Gong, D. (2014). Bank Systemic Risk-Taking and Loan Pricing: Evidence from Syndicated Loans. (CentER Discussion Paper No. 046) (Vol. 46). Tilburg.

Gupta, C. A. R. (2014). An Analysis of Indian Public Sector Banks Using Camel Approach. IOSR Journal of Business and Management (IOSR-JBM), 16(1), 94-102.

Hurka, R. (2017). The Impact of Credit Risk Management on Profitability of Nordic Commercial Banks. Lund University School.

Iqbal, B. A., \& Sami, S. (2017). Role of banks in financial inclusion in India. Contaduria y Administracion, 62(2), 644-656.

Jones, S. A. (2018). Credit Risk. Trade and Receivables Finance, 2(3), 87-98.

Kalu, E. O., Shieler, B., \& Amu, C. U. (2018). Credit Risk Management and Financial Performance of Microfinance Institutions in Kampala, Uganda. Independent Journal of Management \& Production, 9(1), 153

Karugu, B. M., \& Ntoiti, J. (2015). Effect of Credit Risk Management Practices on Profitability of Listed Commercial Banks at Nairobi Securities Exchange in Kenya. IOSR Journal of Economics and Finance Ver. II, 6(5), 2321-5933.

Kayode, O. F., Obamuyi, T. M., Owoputi, J. A., \& Adeyefa, F. A. (2015). Credit Risk and Bank Performance in Nigeria. IOSR Journal of Economics and Finance, 6(4), 21-28

Kessey, K. D. (2015). Assessing Credit Risk Management Practices in. Global Journal of Management and Business Research, 15(6), 2249-4588.

Khan, R. A., \& Ali, M. (2016). Impact of Privatization of Banks on Profitability of Banking Sector in Pakistan. Global Journal of Management and Business Research, 16(1), 2249-4588.

Khodaei, M., Zagherd, W., \& Barghi, M. (2017). Journal of Accounting \& Performance Evaluation of Iranian Banking Industry through CAMELS Framework. Journal of Accounting and Marketing, 6(2). http://doi.org/10.4172/2168-9601.1000228

Khoury, E., \& Salem, C. G. (2018). Ranking and Rating Lebanese Commercial Banks : A CAMELS Framework. International Academic Institute for Science and Technology, 5(4), 49-65. 
Kipruto, J. J., Wepukhulu, J. M., \& Osodo, O. P. (2017). The influence of capital adequacy ratio on the financial performance of second-tier commercial banks in Kenya. International Journal of Business and Management Review, 5(10), 13-23.

Kishori, B., \& Jeslin, S. (2017). A study on the Impact of Credit Risk on the Profitability of State Bank of India (Sbi). ICTACT Journal on Management Studies, 03(02), 538-542. http://doi.org/10.21917/ijms.2017.0073

Kodithuwakku, M. S. (2015). The Impact of Credit Risk Management on Financial Performance of Commercial Banks in Kenya. International Journal of Scientific Research and Innovative Technology, 2(7), 22-37.

Kurawa, J. M., \& Garba, S. (2014). An Evaluation of The Effect of Credit Risk Management (CRM) on The Profitability of Nigerian Banks. Journal of Modern Accounting and Auditing, 10(1), 1548-6583.

Li, F., \& Zou, Y. (2014). The Impact of Credit Risk Management on Profitability of Commercial Banks : Umeå School of Business and Economics.

Maino, R., \& Tintchev, K. (2012). From Stress to CoStress: Stress Testing Interconnected Banking Systems. IMF Working Paper, 12/53. Retrieved from http://www.imf.org/external/pubs/ft/wp/2012/wp1253.pdf

Misra, S. K., \& Aspal, P. K. (2013). A Camel Model Analysis of State Bank Group Misra \& Aspal. World Journal of Social Sciences, 3(4), 36-55.

Mohamed, W. M. (2016). Risk Management of Banking Sector: A Critique Review. American International Journal of Social Science, 5(3), 159-168.

Mumbi, W. M., \& Omagwa, J. (2017). Credit risk management and financial performance of selected commercial banks in Kenya. IOSR Journal of Business Management, 19(11), 92-98

Murigi, D. M., \& Thuo, A. (2018). Credit Risk Management and. International Journal of Economics, Commerce and Management, 6(4), 623-643.

Muritala, T. A., \& Taiwo, A. S. (2016). Credit Management Spur Higher Profitability? Evidence from Nigerian Banking Sector. Journal of Applied Economics and Business, 2(12), 46-53.

Navajas, S., \& Trivelli, C. (2007). Moving Results into Policies and Practice Managing Credit Risk in Rural Financial Institutions in Latin America Managing Credit Risk in Rural Financial Institutions in Latin America. International Conference on Rural Finance Research, 15(3), 15-26.

Nawaz, M. (2012). Credit Risk And Performance Of Nigerian Banks. Interdisciplinary Journal Of Contemporary Research In Business, 4(17), 49-63.

Nguyen, L. (2016). Credit risk control for loan products in commercial banks. Case: Bank for Investment and Development of Vietnam, 1-49. Retrieved from http://www.theseus.fi/bitstream/handle/

Nicholas, W. (2011). Research Methods: The Basics. Madison Avenue, New York, NY 10016: Roultedge. http://doi.org/doi:10.4324/9780203836071

Noman, A. H., Pervin, S., Chowdhury, M. M., \& Banna, H. (2015). The Effect of Credit Risk on the Banking Profitability: A Case on Bangladesh. Global Journal of Management and Business Research: C Finance, 15(3), 41-48.

Odonkor, A. A. (2018). An Assessment of Credit Risk Management Practices of Adansi Rural Bank Limited. International Journal of Economics and Finance, 10(11), 110.

Ofosu-Hene, E. D., \& Amoh, P. (2016). Risk Management and Performance of Listed Banks in Ghana. European Journal of Business Science and Technology, 2(2), 107-121.

Olabamiji, O., \& Michael, O. (2018). Credit Management Practices and Bank Performance : Evidence from First Bank. South Asian Journal of Social Studies and Economics, 1(1), 1-10.

Oluwafemi, S., Israel, N., \& Simeon, O. (2014). Risk Management and Financial Performance of Banks in Nigeria. European Journal of Business and ManagementOnline), 6(31), 2222-2839.

Opoku, A. (2015). The impact of credit risk on profitability of some selected banks in Ghana. Kwame Nkrumah University of Science and Technology, Kumasi: Ghana.

Poudel, R. P. S. (2012). The Impact of Credit Risk Management on Financial Performance of Commercial Banks in Kenya. International Journal of Arts and Commerce, 1(5), $22-37$. http://doi.org/10.5897/AJBM2013.7171

Poudel, S. R. (2018a). Impact of credit risk on profitability of commercial banks in Nepal. Journal of Applied and Advanced Research, 3(6), 161.

Poudel, S. R. (2018b). Impact of Credit Risk on Profitability of Commercial Banks in Nepal. Journal of Applied and Advanced Research, 3(6), 161.

Rostami, M. (2015). Determination of Camels model on bank' s performance. International Journal of Multidiciplinary Research and Development, 2(10), 652-664.

Rundassa, S. G., \& Batra, G. S. (2016). Impact of credit risk management on the financial performance of Ethiopian commercial banks. IOSR Journal of Economics and Finance (IOSR-JEF), 7(16), 108-116.

Serwadda, I. (2018). Impact of Credit Risk Management Systems on the Financial Performance. Journal of Advanced Management Science, 66(6), 1627-1635.

Sheeba, J. (2017). A study on the Impact of Credit Risk on the Profitability of State Bank of India (Sbi). ICTACT 
Journal on Management Studies, 03(02), 538-542.

Sujeewa Kodithuwakku, M., \& Lanka, S. (2015). Impact of Credit Risk Management on the Performance of Commercial Banks in Sri Lanka. International Journal of Scientific Research and Innovative Technology, 2(7), 2313-3759.

Taiwo, J., Ucheaga, E., \& Achugamonu, B. (2017). a Comparative Study on Development Off Small and Medium Enterprises (Smes) in Japan and Malaysia. Saudi Journal of Business and Management Studies, 2(4A), 357374.

Van Greuning, H., \& Brajovic Bratanovic, S. (2009). Analyzing Banking Risk: A Frameworkln for Assessing Corporate Governance and Risk Management, Third Edition (Third Edit). Washington DC, USA: The International Bank for Reconstruction. Retrieved from https://openknowledge.worldbank.org/handle

Wenner, M., Navajas, S., Trivelli, C., \& Tarazona, A. (2007a). Managing Credit Risk in Rural Financial Institutions in Latin America. International Conference on Rural Finance Research, 12(3), 19-21.

Wenner, M., Navajas, S., Trivelli, C., \& Tarazona, A. (2007b). Managing Credit Risk in Rural Financial Institutions in Latin America. Inter-American Development Bank, 3(12), 1-36.

Yeboah-Mensah, E. (2015). Detrminants of Loan Portfolio size of universal banks in Ghana. Accra: University of Ghana. 